\title{
Knowledge, Attitude and Preventive Practices about Ebola Viral Disease among Journalists in Osogbo, Southwest Nigeria
}

\author{
Callistus A Akinleye ${ }^{1}$, Samuel A. Olowookere ${ }^{2}$, Olatunji A Olagunoye ${ }^{3}$, Monisola Omoyeni Oginni ${ }^{4}$, \\ Ayoyinka Olufunmilayo Bolorunduro ${ }^{5}$, Ebenezer G Adepoju ${ }^{6}$ \\ ${ }^{1,3}$ Department of Community Medicine, LAUTECH Teaching Hospital, Osogbo, Nigeria \\ ${ }^{2,5}$ Department of Community Health, Obafemi Awolowo University, Ile-Ife, Nigeria \\ ${ }^{4}$ Department of Nursing Science, Obafemi Awolowo University, Ile-Ife, Nigeria \\ ${ }^{6}$ Department of Preventive Medicine, State Specialist Hospital, Osogbo, Nigeria
}

\author{
Article Info \\ Article history: \\ Received Jul 12, 2018 \\ Revised Sep 2, 2018 \\ Accepted Sep 14, 2018 \\ Keyword: \\ Ebola viral disease \\ Epidemic \\ Journalists \\ Nigeria \\ Risk perception
}

\begin{abstract}
The West African subregion presently faces the Ebola viral disease (EVD) epidemic. In order to control this epidemic, journalists need to inform the public. This study assessed their knowledge, attitude and preventive practices. A descriptive cross-sectional study was conducted among 93 journalists working in Osun State who completed a self administered questionnaire. Data collected was analysed. Mean (SD) age was 26.4 \pm 8.2 years ranging 18 to 49 years. Mean (SD) duration in practising journalism was 7.6 \pm 6.7 years (range, 1-20 years). Most had tertiary education $(87.1 \%$ ), were singles (74.2\%), Christians (51\%) and Yoruba (92.5\%). Despite good knowledge $(58.1 \%)$ of EVD, most had low risk perception $(46.2 \%)$. The only statistical significant predictor of good knowledge was religion. In conclusion, most journalists have good knowledge but low risk perception. Efforts to improve the risk
\end{abstract}

Copyright (C) 2018 Institute of Advanced Engineering and Science. All rights reserved.

\section{Corresponding Author:}

Samuel A. Olowookere,

Department of Community Health,

Obafemi Awolowo University, Ile-Ife, Nigeria.

Email: sanuolowookere@yahoo.com

\section{INTRODUCTION}

Ebola virus disease (EVD) is a major public health problem associated with high case fatality rate. The Ebola virus was responsible for the recent largest, longest, most widespread EVD epidemic in the West African countries of Guinea, Sierra Leone, Liberia, Mali, Senegal and Nigeria [1, 2]. This epidemic was also reported in other countries such as Spain, United States of America mostly of health care workers with contact with affected West African countries [3, 4]. On August 8, 2014, World Health Organization (WHO) declared the epidemic as a Public Health Emergency of International Concern. It far outstrips other previous EVD epidemics that have been reported in other African countries such as Democratic Republic of Congo, Sudan, Gabon and Uganda. A common factor about the countries where the epidemic occurred was the high poverty level with largely destroyed or severely dysfunctional health care system due to conflicts and wars and inability to control this epidemic [2]. This disease is spread by specific situations from one human to another in hospitals with poor infection control mechanism, mortuaries through inappropriate handling of dead bodies and communities with lack or inadequate personal protective equipment with widespread ignorance about the mode of spread of this epidemic hinder its control and prevention [2].

Worldwide, the media are notable agents informing the general public about various topics under the sun [5]. While carrying out this task, some journalists at times misrepresents information gathered, get maimed or die while on duty [6-8]. Most Africans rely on the international media as their source of reliable information even on news and issues concerning the continent. This is mostly due to lack of latest 
technology, poorly trained staff and inappropriate control of news agencies across the continents by governments who owned most of these agencies. Therefore, there is widely no independent news agency that can carry non adulterated news items without being controlled by these government agencies. EVD is highly fatal and has no cure. Also, local beliefs in witchcraft and fear worsen the ability to control and prevent further spread of the disease. This belief sometimes results in family members hiding an infected family member from the surveillance team and taking these infected people to traditional healers with patients avoiding treatment centres. The traditional burial practices encourage the spread of this disease from unsuspecting relatives from the corpse of their dead family member hence the need to change this dangerous funeral practices that involve close contact with infected dead relatives [2].

The role of the international media in informing the people about the Ebola viral disease (EVD) has sensitize the people and government worldwide leading to various attempts at prevention and control of the deadly disease [9-11]. However, since the local media largely depend on the international media for the news carried to their local audience, it is important to assess the knowledge of these local media practitioners to gauge the information available to the general populace. Despite the important role played by these journalists, few studies had assessed their knowledge attitude and preventive practices towards the EVD, hence, the need for this study.

\section{MATERIALS AND METHODS}

Osun State is located in the south-west part of Nigeria. It is home to several media houses which include the Nigeria Television Authority, the State owned Radio and Television stations and several private Radio and Television stations. Also, several print media practitioners work in the State. This cross-sectional study was conducted among journalists working in the print and mass media organisations in Osun State, Nigeria in the month of December 2015. All the journalists on duty during the study period in these media houses were approached to complete a pretested self administered questionnaire on their socio-demographic characteristics, knowledge, attitude and preventive practices to EVD. They were allowed to complete this questionnaire in their spare time. Questionnaire information was anonymised. Ethical approval to conduct this study was taken from the State Hospital Ethics and Research Committee. Written informed consent was taken from the respondents while they were reassured of the confidentiality of the information obtained. The data collected were entered and kept in a password protected computer.

The data obtained were analysed using SPSS version 16. Simple descriptive and inferential statistics were done. Knowledge score was computed for 18-item questions on knowledge of EVD. Each item was assigned " +1 " for correct knowledge and " 0 " for incorrect knowledge. The knowledge score was graded as good or appropriate (if respondent scored $\leq 10$ points) and not good or not appropriate (if score was $>10$ points) using the mean score as the break-off point. Test of significance was conducted using appropriate statistical methods. Multivariate analysis was performed using logistic regression to evaluate sociodemographic variables and other variables that are independently associated with good knowledge of EVD. Adjusted odd ratio (AOR) and 95\% CI were presented and used as measures of the strength of association. Significant level was put at $<0.05$.

\section{RESULTS}

A total of 93 journalists out of 102 approached completed the study. Mean (SD) age was $26.4 \pm 8.2$ years ranging from 18 to 49 years. Mean (SD) duration in practising journalism was 7.6 \pm 6.7 years (range 120 years). Majority were young $(87.1 \%)$, single (74.2\%), had tertiary education $(87.1 \%)$, Christians $(50.5 \%)$, Yoruba (92.5\%) and had 10 years and below length of employment $(66.7 \%)$ as shown in Table 1.

Table 2 shows EVD awareness and source of awareness about the outbreak. Most respondents (88.2\%) were aware of EVD epidemic in West Africa sub region with colleagues and radio as major sources of awareness. Figure 1 reports EVD knowledge among respondents. Majority (58.1\%) had appropriate EVD knowledge. Table 3 reports knowledge of EVD clinical variables by respondents. Majority knows EVD viral aetiology (51.6\%), mode of infection $(68.8 \%)$, prevention $(60.2 \%)$ and that EVD transmission will reduce with good personal and environmental hygiene (51.6\%). Table 4 shows the respondents risk perception and attitude to EVD. Only $46.2 \%$ considered self to be at risk with $48.4 \%$ seeing fellow journalists at risk of EVD infection. About $42 \%$ felt that their workplace is protected from EVD infection with $58.1 \%$ wanting their workplace to have a written EVD control policy. 
Table 1. Socio-Demographic Characteristics of Respondents

\begin{tabular}{lcc}
\hline \multicolumn{1}{c}{ Variable } & Frequency & $\%$ \\
\hline Age group (years) & & \\
18-35 & 81 & 87.1 \\
$\quad$ 35 & 12 & 12.9 \\
Marital status & & \\
$\quad$ Single & 69 & 74.2 \\
$\quad$ Married & 24 & 25.8 \\
Level of education & & \\
$\quad$ Secondary & 12 & 12.9 \\
$\quad$ Tertiary & 81 & 87.1 \\
$\quad$ Religion & & \\
$\quad$ Christianity & 47 & 50.5 \\
Islam & 46 & 49.5 \\
Ethnicity & & \\
$\quad$ Yoruba & 86 & 92.5 \\
$\quad$ Ibo & 7 & 7.5 \\
Duration of employment (years) & & \\
$\quad \leq 10$ & 62 & 66.7 \\
$\quad>10$ & 31 & 33.3 \\
\hline
\end{tabular}

Table 2. EVD Awareness and Source of Awareness about the Outbreak

\begin{tabular}{lll}
\hline \multicolumn{1}{c}{ Variable } & Frequency & $\%$ \\
\hline Aware of the EVD epidemic in & & \\
West Africa & & \\
$\quad$ Yes & 82 & 88.2 \\
$\quad$ No & 11 & 11.8 \\
*Sources of awareness & & \\
$\quad$ Colleagues & 34 & 41.5 \\
Radio & 30 & 36.6 \\
Newspapers & 25 & 30.5 \\
Internet & 19 & 23.2 \\
Television & 16 & 19.5 \\
$\quad$ Notice board/pamphlets & 11 & 13.4 \\
\hline
\end{tabular}

*Multiple responses

Table 3. Knowledge of EVD Clinical Variables

\begin{tabular}{|c|c|c|}
\hline Variable & Frequency & $\%$ \\
\hline \multicolumn{3}{|c|}{ Knows EVD is a viral disease } \\
\hline Yes & 48 & 51.6 \\
\hline No & 45 & 48.4 \\
\hline \multicolumn{3}{|c|}{ Knows EVD clinical presentations } \\
\hline Yes & 42 & 45.2 \\
\hline No & 51 & 54.8 \\
\hline \multicolumn{3}{|l|}{ Knows EVD has no cure } \\
\hline Yes & 42 & 45.2 \\
\hline No & 51 & 54.8 \\
\hline \multicolumn{3}{|c|}{ Knows EVD mode of infection } \\
\hline Yes & 64 & 68.8 \\
\hline No & 29 & 31.2 \\
\hline \multicolumn{3}{|c|}{ Knows how EVD can be prevented } \\
\hline Yes & 56 & 60.2 \\
\hline No & 37 & 39.8 \\
\hline \multicolumn{3}{|c|}{$\begin{array}{l}\text { EVD transmission will reduce with } \\
\text { good personal and environmental } \\
\text { hygiene }\end{array}$} \\
\hline Yes & 48 & 51.6 \\
\hline No & 45 & 48.4 \\
\hline \multicolumn{3}{|c|}{$\begin{array}{l}\text { Suspected cases need special care in } \\
\text { designated hospitals }\end{array}$} \\
\hline Yes & 56 & 60.2 \\
\hline No & 37 & 39.8 \\
\hline
\end{tabular}

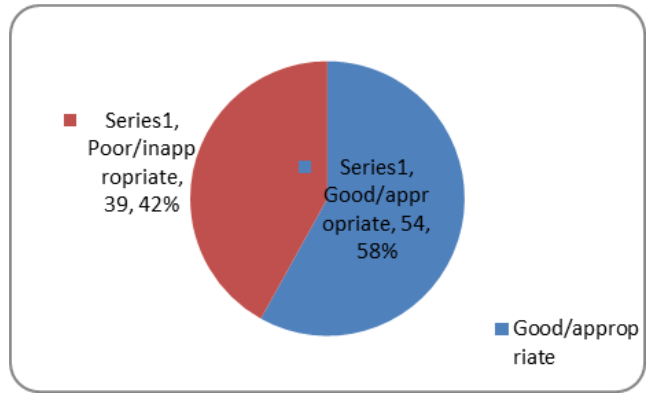

Figure 1. EVD knowledge among respondents

Table 4. Risk Perception and Attitude to EVD/Viral Hemorrhagic Fevers

\begin{tabular}{lcc}
\hline \multicolumn{1}{c}{ Variable } & Frequency & $\%$ \\
\hline Consider self to be at risk & & \\
$\quad$ Agree & 43 & 46.2 \\
Disagree & 34 & 36.6 \\
$\quad$ Undecided & 16 & 17.2 \\
Journalists are prone to EVD infection & & \\
$\quad$ Agree & 45 & 48.4 \\
$\quad$ Disagree & 30 & 32.3 \\
$\quad$ Undecided & 18 & 19.3 \\
EVD cases should be quarantine & & \\
$\quad$ Agree & 74 & 79.6 \\
$\quad$ Disagree & 4 & 4.3 \\
$\quad$ Undecided & 15 & 16.1 \\
My workplace is protected from EVD infection & & \\
$\quad$ Agree & 39 & 41.9 \\
$\quad$ Disagree & 44 & 47.3 \\
$\quad$ Undecided & 10 & 10.8 \\
My workplace should have a written EVD & & \\
control policy & & \\
$\quad$ Agree & 54 & 58.1 \\
$\quad$ Disagree & 27 & 29.0 \\
$\quad$ Undecided & 12 & 12.9 \\
\hline
\end{tabular}

Table 5 shows respondents' preventive practices against EVD infection. Majority avoids eating bush meat since outbreak $(70.7 \%)$, use personal protective equipment $(70.7 \%)$. Some respondents eat bitter kola and salt (12.2\%), avoid handshake with colleagues and other people (19.5\%) and washing hands after touching sick people $(45.1 \%)$. Table 6 shows the association between respondents' characteristics and EVD 
knowledge. Religion is the only characteristic that was statistically significant among respondents. Table 7 shows the logistic regression of respondents' characteristics and EVD knowledge. Religion is the only statistically significant characteristic that predicts good knowledge among respondents.

Table 5. Preventive Practices Against EVD/Viral Hemorrhagic Fevers Infection

\begin{tabular}{lcc}
\hline \multicolumn{1}{c}{ Variable } & Frequency $(\mathrm{n}=82)$ & $\%$ \\
\hline Avoid eating bush meat since outbreak & 58 & 70.7 \\
Yes & 24 & 29.3 \\
No & & \\
Eat bitter kola and salt to prevent EBV infection & 10 & 12.2 \\
$\quad$ Yes & 72 & 87.8 \\
No & 58 & 70.7 \\
Use personal protective equipment to prevent infection & 24 & 29.3 \\
Yes & & \\
No & 16 & 19.5 \\
Avoid handshake with colleagues and other people & 66 & 80.5 \\
Yes & & \\
No & 37 & 45.1 \\
Hand washing after touching sick people & 45 & 54.9 \\
Yes & & \\
No &
\end{tabular}

Table 6. Association between Respondents' Characteristics and EVD Knowledge

\begin{tabular}{|c|c|c|c|c|}
\hline \multirow{2}{*}{ Variable } & \multicolumn{2}{|c|}{ Knowledge } & \multirow{2}{*}{$\chi^{2}$} & \multirow{2}{*}{$\mathrm{p}$-value } \\
\hline & Appropriate $(\%)$ & Inappropriate (\%) & & \\
\hline \multicolumn{5}{|l|}{ Age group (years) } \\
\hline$<36$ & $46(56.8)$ & $35(43.2)$ & & $0.518^{*}$ \\
\hline$\geq 36$ & $8(66.7)$ & $4(33.3)$ & & \\
\hline \multicolumn{5}{|l|}{ Level of education } \\
\hline Secondary & $8(66.7)$ & $4(33.3)$ & & $0.518^{*}$ \\
\hline Tertiary & $46(56.8)$ & $35(43.2)$ & & \\
\hline \multicolumn{5}{|l|}{ Marital status } \\
\hline Single & $36(52.2)$ & $33(47.8)$ & 3.810 & 0.051 \\
\hline Married & $18(75.0)$ & $6(25.0)$ & & \\
\hline \multicolumn{5}{|c|}{ Duration of employment (years) } \\
\hline$\leq 10$ & $35(56.5)$ & $27(43.5)$ & 0.199 & 0.656 \\
\hline$>10$ & $19(61.3)$ & $12(38.7)$ & & \\
\hline \multicolumn{5}{|l|}{ Religion } \\
\hline Christianity & $34(72.3)$ & $13(27.7)$ & 7.953 & 0.005 \\
\hline Islam & $20(43.5)$ & $26(56.5)$ & & \\
\hline \multicolumn{5}{|l|}{ Ethnicity } \\
\hline Yoruba & $52(60.5)$ & $34(39.5)$ & & $0.126^{*}$ \\
\hline Ibo & $2(28.6)$ & $5(71.4)$ & & \\
\hline
\end{tabular}

Table 7. Logistic Regression of Respondents'

\begin{tabular}{|c|c|c|c|}
\hline Variable & AOR & $95 \% \mathrm{CI}$ & p-value \\
\hline \multicolumn{4}{|l|}{ Marital status } \\
\hline Single & 0.469 & $0.159-1.387$ & 0.171 \\
\hline Married (ref) & 1 & & \\
\hline \multicolumn{4}{|l|}{ Ethnicity } \\
\hline Yoruba & 2.200 & $0.377-12.843$ & 0.381 \\
\hline Ibo (ref) & 1 & & \\
\hline \multicolumn{4}{|l|}{ Religion } \\
\hline Christianity & 2.876 & $1.178-7.026$ & 0.020 \\
\hline Islam (ref) & 1 & & \\
\hline
\end{tabular}

\section{DISCUSSION}

This study assessed EVD knowledge, attitude and preventive practices among journalists working in the print and mass media organizations in Osun State, Nigeria. Journalists are in the frontline in getting news to the general public hence are exposed to various people and places while performing this duty [7]. This puts 
the journalist at risk in situations including diseases such as EVD [8,9]. It reported that most journalists were aware of the EVD epidemic in the West African sub-region with colleagues and radio as major sources of information. Previous studies on EVD had reported similar findings [11-13]. The fact that some journalists display ignorance of the EVD epidemic requires urgent attention.

Most respondents were young, single, had tertiary education, Christians and had 10 years and below length of employment. A previous study in this environment reported similar finding [14]. Since the respondents need good health to do their work, this study finding should inform policy direction towards prevention of this life threatening disease. Due to the nature of their work, if infected, they could spread the disease locally to unsuspecting fellow journalist/media practitioners, friends, family members, health care workers, other acquaintances and members of the community [10-14]. Hence, this population should be targeted by more studies assessing their EVD knowledge attitude and preventive practices to inform policy targeted at prevention and controlling EVD epidemic.

This study reported that although majority had good knowledge, some respondents had poor knowledge. This further reinforce that journalists need to undergo targeted education on EVD so as to improve their knowledge of this deadly disease. This study reported that the source of information on EVD for most journalists that participated was not the internet. This implies that journalists do not access information from reliable sources such as the internet. Hence the media organisations that employed these journalists need encouragement to provide internet facilities for their staff and encourage them to use it.

Most journalists display low risk perception as they neither see themselves nor their colleagues at risk of EVD. This negative attitude could lead to poor prevention preparedness and control of this deadly epidemic hence urgent action must be taken to put in place policies that will control and reduce the burden of the disease. The need to establish the EVD policy in the workplace will help to control this epidemic $[11,14]$.

Although, some preventive practices such as handwashing had been proven to be effective in controlling the EVD epidemic, however, the use of bitter kola and salt require further investigation. The finding in this study that religion was the only socio-demographic factor that predict good knowledge needs further investigation. However, some religious practices have been proven to encourage spread of EVD such as performance of burial rites on patients that died from EVD [15-18].

This baseline study among Nigerian journalists is limited by its cross-sectional study design. Also, some respondents could have given socially acceptable answers to some questions despite assurances on the purpose of this study. It is however expected that this study will guide planning and implementing interventions targeted at controlling possible epidemics among this highly mobile study population.

\section{CUNCLUSION}

In conclusion, some journalists had inappropriate EVD knowledge. Efforts to improve the journalists' risk perception and public education focusing on the concept of universal precautions are required. Also, EVD control policy and emergency preparedness towards possible EVD epidemic is necessary.

\section{ACKNOWLEDGEMENTS}

The authors are grateful to members of the Osun State branch of the National Union of Journalists that participated in this study.

\section{REFERENCES}

[1] Feldmann H, Geisbert TW, Ebola Haemorrhagic Fever. Lancet 2011; 377: 849-862.

[2] Chan M., "Ebola Virus Disease in West Africa-No early end to the outbreak," NEJM, 371: 1183-1185, 2014.

[3] Lyon GM, Mehta AK, Varkey JB, Brantly K, Plyler L, McElroy AK, Kraft CS, Towner JS, Spiropoulou C, Stroher U, Uyeki TM, Ribner BS., "Clinical care of two patients with Ebola virus disease in the United States" NEJM, 371 : 2402-9, DOI: 10.1056/NEJMoa1409838, 2014.

[4] Kreuels B, Wichmann D, Emmerich P, Schmidt-Chanasit J, de Heer G, Kluge S, Sow A, Renne T, Gunther S, Lohse AW, Addo MM, Schmiedel S., "A Case of Severe Ebola Virus Infection Complicated by Gram Negative Septicemia" NEJM, 371: 2394-401. DOI: 10.1056/NEJMoa1411677.

[5] Garrett L., "Understanding media's response to epidemics" Public Health Rep.116 (Suppl 2):87, 2001.

[6] Holman EA, Garfin DR, Silver RC., "Media's Role in Broadcasting Acute Stress Following The Boston Marathon Bombings" Proc Natl Acad Sci USA, 111: 93-98, 2014.

[7] Cullen T., "HIV/AIDS: 25 Years of Press Coverage" Aust Journal Rev, 28(2):187, 2006.

[8] Du Cille M., "Documenting with Dignity in the Ebola Zone-The Washington Post" The Washington Post, https://www.washingtonpost.com/lifestyle/style/documenting-with-dignity-in-the-ebolazone/2014/10/19/07c41fd25638-11e4-ba4b-f6333e2c0453_story.html. Published October 19, 2014. Accessed April 24, 2016. 
[9] Adeyanju C.T, Oriola T., "Not in Canada: The non-Ebola Panic and Media Misrepresentation of the Black Community" African Journal of Criminology and Justice Studies, 4: 32-54, 2010.

[10] Lubens P., Journalists and public health professionals: Challenges of a symbiotic relationship. Disaster Medicine and Public Health Preparedness.

[11] Matloff J., "Reporters Struggle to Stay Safe Covering Ebola. Columbia Journalism Review," http://www.cjr.org/behind_the_news/dangers_of_reporters_covering.php. Published October 7, 2014. Accessed April 24, 2016.

[12] Clark R.P., From AIDS to Ebola: Journalism, Disease and the Mentality of Fear. http://www.poynter.org/2014/from-aids-to-ebola-journalism-disease-and-the-mentality-of-fear/276913/. Published October 24, 2014. Accessed April 24, 2016.

[13] Bernstein L., Reporting on Ebola: First rule is you don't touch anyone. https://www.washingtonpost.com/news/toyour-health/wp/2014/10/01/reporting-on-ebola-first-rule-is-you-dont-touch-anyone/. Published October 1, 2014. Accessed April 24, 2016.

[14] Olowookere S.A., Abioye-Kuteyi E.A., Adepoju O.K, Esan O.T., Adeolu T.M., Adeoye T.K., Adepoju A.A., Aderogba A.T., "Knowledge, Attitude, and Practice of Health Workers in a Tertiary Hospital in Ile-Ife, Nigeria, towards Ebola Viral Disease" 1-6, 2015.

[15] Center for Public Policy Alternatives, Study on the Ebola Virus Disease (EVD) Knowledge, Attitudes and Practices of Nigerians in Lagos State, Center for Public Policy Alternatives, 2014.

[16] Cozma V.S., Attitudes and Practices (KAP) Survey on the Ebola Virus Disease (EVD) Kailahun and Kenema Districts, Sierra Leone, International Federation of Red Cross and Red Crescent Societies, Geneva, Switzerland, 2014.

[17] Grady D. "With Ebola cases still few, populous Nigeria has chance to halt its outbreak," The New York Times, 2014, http://nyti.ms/1mSQTu2.

[18] Brown C., Arkell P., Rokadiya S. Ebola Virus Disease: the black swan in West Africa. Tropical Doctor. 2015; 45 : $2-5$. 